\title{
Respon Pertumbuhan Setek Cincau ( Premna oblongifolia Merr.) yang Direndam Dalam Berbagai Konsentrasi Air Kelapa
}

\author{
Ana, Farida Iriani* dan Sri Nur Widyastuti L. \\ Program Studi Agroteknologi Fakultas Pertanian Universitas Bandung Raya \\ Jl. Banten No. 11 Bandung. 40272 \\ Email: farida_iriani52@unbar.ac.id (*Penulis untuk korespondensi)
}

\begin{abstract}
ABSTRAK
Tanaman cincau merupakan salah satu jenis tanaman pangan yang sudah sejak dulu dimanfaatkan penduduk untuk mengobati berbagai penyakit. Kembali maraknya variasi pangan tradisional, maka dianggap perlu adanya perluasan areal sentra penanaman sehingga berakibat penambahan jumlah pengadaan bibit. Perbanyakan tanaman cincau hanya efektif melalui organ vegetatif, yaitu melalui setek batang. Upaya stimulasi keberhasilan perbanyakan melalui setek dapat dengan penggunaan zat pengatur tumbuh alami seperti air kelapa. Penelitian ini bertujuan untuk memperoleh informasi berapa konsentrasi air kelapa yang tepat untuk memacu pertumbuhan setek cincau. Percobaan menggunakan Rancangan Acak Kelompok (RAK) yang terdiri atas lima perlakuan dan lima ulangan, yaitu: A konsentrasi air kelapa 0\%, B konsentrasi air kelapa 15\%, C konsentrasi air kelapa 30\%, D konsentrasi air kelapa 45\%, dan E konsentrasi air kelapa 60\%. Data yang diperoleh dianalisis dengan sidik ragam pada taraf uji 5\%, kemudian dilanjutkan dengan uji Duncan pada taraf signifikansi 5\%. Hasil penelitian menunjukkan bahwa pemberian air kelapa adalah positif terhadap percepatan pertumbuhan setek tanaman cincau. Perendaman setek dalam air kelapa sebelum tanam pada konsentrasi 30\%, mampu menstimulasi jumlah tunas dan jumlah daun, sedangkan pada konsentrasi $45 \%$ menstimulasi jumlah akar adventif terbanyak pada tanaman cincau hijau perdu baru.
\end{abstract}

Kata kunci : setek cincau, air kelapa, konsentrasi.

\section{PENDAHULUAN}

Tanaman cincau hijau (Premna oblongifolia Merr) merupakan jenis tanaman perdu asli Indonesia dari keluarga Verbenaceae, dan kelas Liliopsida. Beradaptasi tumbuh pada dataran rendah maupun dataran tinggi, yaitu 50-1000 mdpl (Pitojo dan Zumiati, 2008). Bagian daun dimanfaatkan sebagai bahan pangan dan non pangan. Sebagai bahan pangan tradisional dan fungsional, dapat mengobati berbagai penyakit, antara lain penyakit sariawan dan panas dalam (Pitojo dan Zumiati, 2008) akibat tingginya kadar khlorofil (Wulandari et al., 2013), menurunkan tekanan darah tinggi (Sundari et al., 2014), mengatasi radang lambung dan sistem pencernaan (Muhlisah, 2012), serta sebagai anti oksidan dan obat penyakit yang disebabkan karsinogen (Nurdin et al., 2017), khususnya tumor otak (Santoso, 2018). Sebagai bahan non pangan, ekstrak polisakarida pektin dari daun cincau hijau dapat dibuat gel pengharum ruangan (Kariza, 2015). 
Bagaimana menyediakan bibit tanaman cincau agar efektif efisien, maka perlu upaya perbaikan teknik perbanyakan vegetatif sehingga dapat mempersingkat waktu pengadaan bibit. Perbanyakan tanaman secara vegetatif, terutama dengan setek batang (Ashari, 2006; Gunawan, 2014) memiliki beberapa keuntungan antara lain yaitu teknik pelaksanaan mudah, diperoleh banyak bahan setek dari satu tanaman induk, dan dipastikan akan memiliki sifat gen yang sama dengan induknya. Namun ada pula kelemahan perbanyakan dengan cara setek, yaitu perakaran didominasi akar adventif, tidak memiliki akar tunggang sehingga kurang kokoh dan mudah roboh bila tertiup angin kencang. Keberhasilan perbanyakan tanaman melalui setek dicirikan oleh terbentuknya akar adventif yang berkaitan dengan ketersediaan zat pengatur tumbuh akusin dan atau sitokinin dalam bahan setek (Ashari, 2006), serta terbentuknya tunas daun akibat bekerjanya sistem keseimbangan antara sitokinin dan auksin di dalam bahan setek (Hartman et al., 1997).

Beberapa hasil penelitian yang telah dilakukan para ahli sebelumnya menunjukkan bahwa, pemberian zat pengatur tumbuh terutama dari kelompok auksin dan sitokinin, baik secara alami maupun sintetis dapat mempercepat pertumbuhan tunas daun dan akar dari bahan setek. Salah satu zat pengatur tumbuh alami adalah air kelapa. Air kelapa mudah diperoleh, murah, dan ramah lingkungan. Hasil penelitian Kristina dan Syahid (2012), bahwa air kelapa mengandung vitamin C $\left(0,9 \mathrm{mg} . \mathrm{L}^{-1}\right)$, Biotin $\left(2,1 \mathrm{mg} \cdot \mathrm{L}^{-1}\right)$, unsur N $(0,4$ mg. $\left.\mathrm{L}^{-1}\right)$ dan unsur Ca $\left(22,4 \mathrm{mg} . \mathrm{L}^{-1}\right)$. Hasil penelitian Savitri dan Hermawan (2005) dalam Rusmayasari (2006), ditemukan zat pengatur tumbuh dari kelompok sitokinin, auksin, dan giberelin dalam jumlah yang berbeda di dalam air kelapa tua dan air kelapa muda. Sedangkan Karimah et al. (2013) melaporkan terdapat sitokinin sejumlah 5,8 $\mathrm{mgL}^{-1}$ dan auksin sejumlah $0,07 \mathrm{mgL}^{-1}$ di dalam air kelapa muda. Berdasarkan hasil penelitian Widiastoety et al. (1997), bahwa pembentukan tunas dan deferensiasi jaringan baru akan berlangsung lebih baik apabila konsentrasi sitokinin lebih besar daripada auksin.

Hasil penelitian Manurung et al. (2017), pemberian air kelapa konsentrasi 50\% mampu meningkatkan panjang tunas, sedangkan konsentrasi air kelapa 100\% mampu meningkatkan luas daun pada batang atas hasil okulasi tanaman karet klon PB 260 dengan batang bawah klon GT 1. Sedangkan Fanesa (2011) dalam Visa dan Ratih (2018), bahwa pemberian air kelapa muda konsentrasi $25 \%$ berpengaruh terbaik terhadap pertumbuhan setek jeruk kacang (Citrus reticulata). Aplikasi air kelapa $600 \mathrm{mlL}^{-1}$ berpengaruh baik terhadap pertumbuhan vegetatif benih cengkeh (Mayura et al., 2016). Wulandari et al. (2013) melaporkan hasil penelitiannya bahwa pemberian air kelapa pada konsentrasi $60 \%$ meningkatkan pertumbuhan jumlah daun, berat segar tajuk dan berat kering tajuk setek 
melati putih. Sedangkan Karimah et al. (2013) melaporkan bahwa, perendaman rimpang temulawak dalam air kelapa konsentrasi 50\% dapat meningkatkan indeks vigor (16\%), dan daya berkecambah tunas $(92 \%)$.

Bagaimana respon setek cincau terhadap perendaman dalam air kelapa sebelum tanam, dan berapa konsentrasi air kelapa yang efektif agar mampu menstimulasi pertumbuhan tunas daun dan akar, merupakan tujuan akhir dari percobaan ini. Informasi yang diperoleh dari hasil percobaan, diharapkan dapat menjadi rekomendasi yang bermanfaat bagi upaya perbaikan perbanyakan vegetatif khususnya bagi tanaman dari famili Verbenaceae ataupun tanaman jenis perdu dari keluarga lainnya.

\section{BAHAN DAN METODE}

Penelitian telah dilaksanakan pada bulan Maret s.d Mei 2018 dalam rumah plastik di Kampung Pojok Sukamulya, Desa Mekarwangi, Kecamatan Lembang, Kabupaten Bandung Barat, pada ketinggian tempat $1.200 \mathrm{mdpl}$, suhu rata- rata harian $20-28{ }^{\circ} \mathrm{C}$, dan jenis tanah Alluvial (Monografi Desa Mekarwangi, 2018).

Alat yang digunakan dalam percobaan adalah polybag ukuran 24 x $28 \mathrm{~cm}$, gunting setek, gelas ukur $500 \mathrm{~mL}$ dan $1000 \mathrm{~mL}$, baskom plastik, kertas label, penggaris, dan jangka sorong. Bahan yang digunakan dalam percobaan, yaitu setek batang cincau hijau perdu varietas lokal, media tanah, pupuk kandang sapi, dan kompos dengan perbandingan $2: 1: 1$, air kelapa muda, dan akuades.

Metode yang digunakan adalah Rancangan Acak Kelompok (RAK) satu faktor. Jumlah setiap perlakuan ada lima setek, dan setiap perlakuan diulang lima kali. Total setek yang dibutuhkan ada 125 buah, dan 25 buah untuk setek cadangan, berasal dari tanaman induk berusia 4 tahun, panjang setek $20 \mathrm{~cm}$, dengan tingkat keseragaman bahan setek $98 \%$. Lima jenis perlakuan dalam percobaan, yaitu :

$\mathrm{A}=$ Konsentrasi air kelapa $0 \%$

$\mathrm{B}=$ Konsentrasi air kelapa $15 \%$

$\mathrm{C}=$ Konsentrasi air kelapa $30 \%$

$\mathrm{D}=$ Konsentrasi air kelapa $45 \%$

$\mathrm{E}=$ Konsentrasi air kelapa $60 \%$ 
Model linier Rancangan Acak Kelompok, adalah menurut (Gomez \& Gomez, 1995) :

$$
x_{i j}={ }^{u}+t_{i}+r_{j}+e_{i j}
$$

Keterangan:

$\mathrm{X}_{\mathrm{ij}} \quad$ : Hasil pengamatan perlakuan ke-i dalam ulangan ke-j

u $\quad$ : Rata-rata umum

$t_{i} \quad$ : Pengaruh perlakuan ke-i $(i=1,2, \ldots . t)$

$\mathrm{r}_{\mathrm{j}} \quad$ : Pengaruh ulangan ke-j $(\mathrm{j}=1,2, \ldots . . \mathrm{r})$

$\mathrm{e}_{\mathrm{ij}} \quad$ : Pengaruh faktor random terhadap perlakuan ke-i pada ulangan ke-j

Ditambahkanya bahwa berdasarkan model linier RAK seperti di atas, maka dapat disusun analisis ragam seperti pada Tabel 1. berikut :

Tabel 1. Analisis Ragam Rancangan Acak Kelomok (RAK)

\begin{tabular}{clcccc}
\hline No & Sidik keragaman & DB & Jumlah Kuadrat & Kuadrat tengah & $\mathrm{F}_{\mathrm{h}}$ \\
\hline 1 & Ulangan & $\mathrm{r}-1$ & $\sum \mathrm{xj}_{. .}{ }^{2} / \mathrm{t}-\mathrm{x} . .^{2} / \mathrm{rt}$ & JKU/DBU & KTU/KTG \\
2 & Perlakuan & $\mathrm{t}-1$ & $\sum \mathrm{xi..} / \mathrm{r}-\mathrm{x} . .^{2} / \mathrm{rt}$ & JKP/DBP & KTP/KTG \\
3 & Galat & $(\mathrm{r}-1)(\mathrm{t}-1)$ & $\mathrm{Jk}$ Total $-\mathrm{Jk}$ Ulangan - & JKG/DBG & \\
4 & Total & $\mathrm{rt}-1$ & $\sum \sum \mathrm{xij}^{2} / 1-\mathrm{x} . .^{2} / \mathrm{rt}$ & & \\
\hline
\end{tabular}

Untuk mengetahui perlakuan mana yang menunjukkan perbedaan dilakukan uji lanjut dengan Uji Jarak Berganda Duncan pada taraf 5\% sebagaimana rumus berikut:

$\mathrm{Sx}=\frac{\sqrt{\text { KT galat }}}{\mathrm{r}}$

Setek yang sudah siap untuk diperlakukan, direndam dalam air kelapa muda yang dipetik dari kebun 2 hari sebelumnya. Air kelapa dikeluarkan, disaring, dan ditampung pada wadah. Disiapkan lima wadah (baskom) yang telah diberi label perlakuan, diisi akuades, kemudian ditambahkan air kelapa sesuai perlakuan, seperti yang disajikan pada Tabel 2. Sebelum setek direndam selama 24 jam, campuran kedua cairan tersebut diaduk merata.

Tabel 2. Konsentrasi air kelapa untuk perendaman setek batang cincau hijau (mL).

\begin{tabular}{cccc}
\hline $\begin{array}{c}\text { Perlakuan } \\
\text { \% Air Kelapa }\end{array}$ & Volume akuades & Volume air kelapa & Total Volume \\
\hline $\mathrm{A}=0$ & 1.000 & 0 & 1.000 \\
$\mathrm{~B}=15$ & 850 & 150 & 1.000 \\
$\mathrm{C}=30$ & 700 & 300 & 1.000 \\
$\mathrm{D}=45$ & 550 & 450 & 1.000 \\
$\mathrm{E}=60$ & 400 & 600 & 1.000 \\
\hline
\end{tabular}


Penanaman setek cincau dilakukan pada sore, dilanjutkan dengan penyiraman setiap pagi hari, dan penyiangan gulma jika ada. Adapun peubah respon pertumbuhan setek cincau diamati pada hari ke 35 setelah tanam (hst), yaitu:

1. Jumlah akar, dihitung banyaknya akar yang terbentuk dari setiap setek (helai).

2. Panjang akar, diukur dari leher akar sampai ujung akar terpanjang $(\mathrm{cm})$.

3. Jumlah tunas, dihitung jumlah tunas dari setiap setek yang tumbuh (helai).

4. Panjang tunas, diukur dari pangkal tunas sampai ujung titik tumbuh tunas $(\mathrm{cm})$.

5. Jumlah daun, dihitung seluruh jumlah daun yang tumbuh dari setiap setek (helai).

\section{HASIL DAN PEMBAHASAN}

Hasil analisis statistik respon pertumbuhan setek cincau hijau perdu terhadap jumlah akar, jumlah tunas, dan jumlah daun memberikan hasil yang berbeda nyata akibat perbedaan konsentrasi air kelapa, sedangkan untuk peubah respon panjang akar, dan panjang tunas tidak berbeda nyata akibat perbedaan konsentrasi air kelapa menurut uji jarak berganda Duncan taraf 5\% sebagaimana yang disajikan pada Tabel 3 berikut ini.

Tabel 3. Respon pertumbuhan setek cincau hijau setelah direndan air kelapa terhadap peubah yang diamati.

\begin{tabular}{|c|c|c|c|c|c|}
\hline $\begin{array}{c}\text { Perlakuan \% } \\
\text { Air Kelapa }\end{array}$ & $\begin{array}{c}\text { Jumlah } \\
\text { Akar }\end{array}$ & $\begin{array}{c}\text { Panjang } \\
\text { Akar }\end{array}$ & $\begin{array}{c}\text { Jumlah } \\
\text { Tunas }\end{array}$ & $\begin{array}{l}\text { Panjang } \\
\text { Tunas }\end{array}$ & $\begin{array}{c}\text { Jumlah } \\
\text { Daun }\end{array}$ \\
\hline $\mathrm{A}=0$ & 3,80 a & 1,77 a & $2,07 \mathrm{a}$ & $3,21 \quad \mathrm{a}$ & 6,20 a \\
\hline$B=15$ & 3,47 a & 1,92 a & $2,13 \mathrm{ab}$ & 3,13 & 6,33 \\
\hline$C=30$ & $5,73 \mathrm{ab}$ & $2,26 \mathrm{a}$ & $2,73 \quad b$ & 3,90 & 8,53 \\
\hline $\mathrm{D}=45$ & $6,20 \quad b$ & 2,63 a & $2,67 \mathrm{ab}$ & 3,98 & 7,47 \\
\hline$E=60$ & 3,60 & $2,47 \quad \mathrm{a}$ & $2,13 \mathrm{a}$ & 4,79 a & 7,00 \\
\hline
\end{tabular}

Keterangan : Angka yang diikuti oleh huruf yang sama pada kolom yang sama, berbeda tidak nyata menurut uji berganda Duncan taraf 5\%

Berdasarkan Tabel 3. di atas, nampak bahwa ada peran fungsional dari konsentrasi air kelapa yang diperlakukan terhadap respon pertumbuhan setek cincau hijau perdu. Perendaman bahan setek cincau sebelum tanam selama 24 jam di dalam air kelapa pada konsentrasi $30 \%$ adalah terbaik untuk peubah jumlah tunas yang diikuti oleh peubah jumlah daun. Perendaman bahan setek cincau sebelum tanam selama 24 jam di dalam air kelapa pada konsentrasi $45 \%$ adalah terbaik untuk peubah jumlah akar. Sedangkan perendaman bahan setek cincau sebelum tanam selama 24 jam di dalam air kelapa pada konsentrasi $60 \%$ tidak ada perbedaan yang nyata dengan perendaman setek cincau dalam akuades saja. 


\section{Pertunasan}

Pertumbuhan setek cincau hijau (Premna oblongifolia Merr.) yang direndam dalam air kelapa selama 24 jam sebelum tanam pada konsentrasi 30\% dan $45 \%$ memberikan respon positif terhadap pertumbuhan jumlah tunas, jumlah daun, dan jumlah akar, tetapi pada konsentrasi air kelapa 60\% tidak memberi respon positif terhadap semua peubah yang diamati. Hasil ini sejalan dengan konsep kerja kadar zat pengatur tumbuh seperti yang dikemukakan oleh Hartman et al. (1997), yaitu zat pengatur tumbuh bekerja sebagai pemacu tumbuh hanya dalam konsentrasi rendah yang optimum bagi suatu jenis tumbuhan, tetapi menjadi tidak efektif jika diberikan dalam konsentrasi sangat rendah atau sangat tinggi.

Berbeda dengan hasil penelitian Wulandari et al. (2013), bahwa pemberian air kelapa pada konsentrasi $60 \%$ dapat meningkatkan jumlah daun, berat segar tajuk, dan berat kering tajuk setek melati putih. Hal ini disebabkan oleh perbedaan spesies, asal bahan, dan jenis media tanam (Istomo, et al., 2014) atau faktor lingkungan lainnya selama bahan setek diperlakukan, namun pada prinsipnya adalah sama, yaitu bahwa kandungan sitokinin dan auksin yang terdapat di dalam air kelapa muda bersinergi aktif dalam menstimulasi pembelahan sel, meningkatkan plastisitas dan pengembangan dinding sel, meningkatkan metabolisme asam nukleat sehingga sel mampu berdiferensiasi untuk terjadinya pertunasan dan diikuti oleh pembentukan daun (Karimah et al., 2013; Wulandari et al., 2013). Ditambahkan oleh Widiastoety et al. (1997), bahwa pembentukan tunas yang dilanjutkan dengan proses diferensiasi menjadi daun akan berjalan baik apabila terjadi interaksi antara auksin dan sitokinin dengan posisi konsentrasi sitokinin lebih besar daripada auksin. Hasil ini didukung oleh laporan Setiawan (2013), bahwa kadar sitokinin adalah sebesar 5,8 $\mathrm{mgL}^{-}$

${ }^{1}$ dan auksin sebesar $0,07 \mathrm{mgL}^{-1}$ di dalam air kelapa muda.

Banyaknya jumlah tunas yang kemudian diikuti oleh banyaknya jumlah daun akibat perlakuan perendaman bahan setek cincau dalam air kelapa konsentrasi 30\%, memberi informasi bahwa peran sitokinin dalam air kelapa berada dalam takaran optimum untuk aktif mengabsorpsi air dan linarut tanah, diduga terutama $\mathrm{N}, \mathrm{P}, \mathrm{Mg}, \mathrm{Fe}$, dan $\mathrm{Cu}$ yang berperan dalam meningkatkan tekanan osmotik sel, sintesis protein dan aktifitas fotosintesis sehingga memacu pertumbuhan, terutama tunas dan daun.

\section{Perakaran}

Respon positif juga diperoleh akibat perendaman setek cincau hijau di dalam air kelapa muda konsentrasi $45 \%$, yaitu mampu menstimulasi terbentuknya akar adventif pada 
dasar setek, hal ini menginformasikan bahwa keseimbangan sinergis antara sitokinin dan auksin pada konsentrasi $45 \%$ dicapai dalam memacu terbentuknya sistem perakaran setek tanaman cincau hijau perdu. Kristina dan Syahid (2012) melaporkan bahwa, air kelapa muda juga mengandung beberapa vitamin dan mineral, terutama didominasi oleh vitamin C sebesar $\left(8,6 \mathrm{mgL}^{-1}\right)$ dan vitamin $\mathrm{B}\left(21,4 \mathrm{mgL}^{-1}\right)$, serta unsur hara $\mathrm{N}\left(43 \mathrm{mgL}^{-1}\right)$ dan $\mathrm{Ca}\left(224,7 \mathrm{mgL}^{-1}\right)$.

Terbentuknya akar adventif atau akar serabut pada dasar setek, merupakan salah satu ciri keberhasilan setek (Ashari, 2006). Sistem perakaran serabut terbentuk setelah bagian batang dipotong dan terjadi luka yang didominasi oleh jaringan kalus. Bagian bekas potongan tanaman cincau perdu itu bersifat meristematik, sel-sel berdiferensiasi kembali membentuk jaringan primordia akar, dan akar-akar adventif tersebut sangat efektif dalam penyerapan air dan linarut dari dalam tanah (Hartman et al., 1997). Kemudahan dalam terbentuknya akar adventif pada dasar setek, sangat dipengaruhi oleh kadar zat pengatur tumbuh yang terdapat dalam bahan setek, baik internal maupun yang ditambahkan secara eksternal. Dari semua kelompok zat pengatur tumbuh tanaman yang paling berperan memacu pertumbuhan akar adalah auksin. Di dalam tubuh tanaman, auksin bergerak secara basipetal, yaitu bergerak dari atas ke bawah tetapi bukan karena efek dari gravitasi. Efek fisiologis dari auksin terhadap pertumbuhan akar adalah memacu pembesaran sel, formasi akar, dan mengaktifkan kerja lapisan kambium untuk membentuk jaringan xylem dan floem (Hartmann et al., 1997).

Hasil penelitian seperti yang disajikan dalam Tabel 3. menginformasikan bahwa perendaman setek cincau dalam air kelapa pada konsentrasi $45 \%$ berhasil memacu pertumbuhan jumlah akar adventif terbanyak dibandingkan dengan konsentrasi lainnya atau perendaman tanpa air kelapa. Menurut Hartmann et al. (1997), adakalanya di dalam tubuh tanaman terdapat senyawa endogen yang dapat menghambat perakaran sehingga setek sulit membentuk akar, contoh pada setek tanaman Anggur. Ditambahkannya pula, berdasarkan analisis khromatografi, ditemukan dua jenis senyawa organik yang bersifat menghambat perakaran setek anggur, namun jika dasar setek sebelum tanam dicuci dengan air, kedua senyawa tersebut ikut tercuci sehingga perakaran setek segera terbentuk. Pendapat Hartmann et al. (1997), mendukung hasil penelitian ini, yaitu setek cincau hijau perdu sebelum tanam direndam dalam air kelapa dan atau akuades selama 24 jam, diperkirakan dapat mencuci senyawa endogen yang dapat menghambat terbentuknya akar adventif. Hasil penelitian juga memberi informasi bahwa perendaman setek dalam air kelapa konsentrasi $45 \%$ merupakan takaran optimum untuk menghilangkan efek buruk 
senyawa endogen yang mungkin akan menghambat pertumbuhan akar. Sejalan dengan hasil penelitian Djamhuri (2011), bahwa pemberian air kelapa pada setek pucuk meranti tembaga (Shorea leprosula Miq) dapat menggantikan perlakuan pemberian auksin IBA atau NAA masing-masing pada konsentrasi 100 ppm, yaitu meningkatkan persentase terbentuknya akar, dan berat kering akar. Selain itu menurut Kristina dan Syahid (2012), air kelapa mengandung Kalium cukup tinggi (14\%), dan Fosfor (13\%). Unsur Kalium diperlukan dalam proses terbentuknya sel-sel meristem apikal pada primordia akar hingga munculnya akar-akar baru (Hartman et al., 1997). Jumlah akar pada setek cincau hijau perdu dapat dilihat pada Gambar 1 berikut ini.

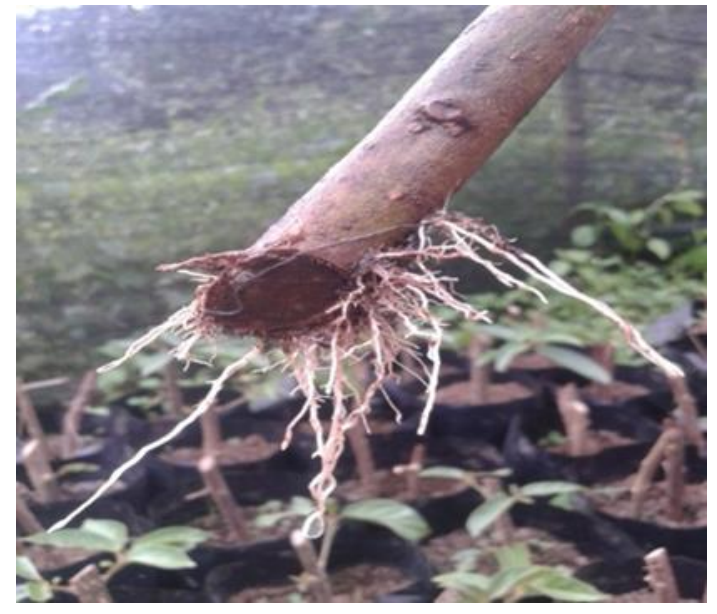

Gambar 1. Perakaran pada setek cincau hijau perdu

\section{KESIMPULAN}

Perendaman bahan setek hijau perdu dalam air kelapa selama 24 jam sebelum tanam, pada konsentrasi 30\% dapat meningkatkan jumlah jumlah tunas dan jumlah daun, sedangkan pada konsentrasi $45 \%$ dapat meningkatkan jumlah akar. Air kelapa dapat direkomendasikan untuk menstimulasi pertunasan dan perakaran pada setek cincau hijau perdu.

\section{UCAPAN TERIMA KASIH}

Terima kasih disampaikan dengan hormat kepada seluruh Tim Panitia Program Dosen Merenung 2019 Direktorat Karier dan Kompetensi Sumber Daya Manusia Dikti yang telah memotivasi dan mendanai penulisan artikel ini. Terima kasih juga disampaikan kepada Dekan, mitra Prof.Dr.H. Zulkarnain, Editor Team J. Agroecotania, seluruh dosen dan staf Program Studi Agroekoteknologi Fakultas Pertanian Universitas Jambi yang telah bekerjasama dengan baik selama penulis mengikuti kegiatan Program Dosen Merenung 2019. 


\section{DAFTAR PUSTAKA}

Ashari, S. 2006. Hortikultura Aspek Budidaya. Universitas Indonesia Press, Jakarta. 490 hal. ISBN: 9794561495

Djamhuri, E. 2011. Pengaruh Air Kelapa Terhadap Pertumbuhan Setek Pucuk Meranti (Shorea leprosula Miq). J. Silvikultur Tropika 2 (1) : 5-8

Gomez, A.K dan A.A. Gomez. 1995. Prosedur Statistik untuk Penelitian Pertanian. Penerbit Universitas Indonesia Press.

Gunawan, E. 2014. Perbanyakan Tanaman, Cangkok, Setek, Okulasi, Sambung dan Biji. Penerbit PT Agromedia Pustaka, Jakarta.

Hartman, H.T, D.E. Kester, F.T. Davies, dan R.L Geneve. 1997. Plant Propagation : Principles and Practice. Ed ke-6. Englewood Cliffs, New Jersey : Prentice Hall.

Istomo, A.Subiakto, dan S.Rahmadianto. 2014. Pengaruh Asal Bahan dan Media Setek Terhadap Keberhasilan Setek Pucuk Tembesu Fragraea fragrans. Berita Biologi 13 (3) : 275-281.

Karimah, A., Purwanti, S. dan Rogomulyo, R. 2013. Kajian Perendaman Rimpang Temulawak (Curcuma xhantorriza Roxb) dalam Urin Sapi dan Air Kelapa untuk Mempercepat Pertunasan. J. Vegetalika 2 (2) : 1-6

Kariza, D.A. 2015. Ekstraksi Pektin dari Cincau Hijau (Premna oblongifolia Merr) untuk Pembuatan Gel Pengharum Ruangan. (Skripsi) Universitas Negeri Semarang.

Kristina, N.N dan S.F Syahid. 2012. Pengaruh Air Kelapa terhadap Multiplikasi Tunas in vitro, Produksi Rimpang, dan Kandungan Xanthorrhizol Temulawak di Lapangan. J. Penelitian Tanaman Industry. 18 (3) : 125-134.

Manurung, Desri.E.B, Y.B.S. Heddy, dan D. Haryono. 2017. Pengaruh Pemberian Air Kelapa pada Beberapa Batang Atas terhadap Pertumbuhan Bibit Karet (Hevea brasiliensis Muel Arg) Hasil Okulasi. Jurnal Produksi Tanaman 5 (4): 686-694.

Mayura, E., Yudarfis, Herwita I., dan Ireng D. 2016. Pengaruh Pemberian Air Kelapa dan Frekuensi Pemberian terhadap Pertumbuhan Benih Cengkeh. BulLitro27(2): 123128

Muhlisah, F. 2012. Tanaman Obat Keluarga. Penerbit Penebar Swadaya, Jakarta.

Monografi Desa Mekarwangi, Kecamatan Lembang, Kabupaten Bandung Barat. 2018.

Nurdin, S.U; R.K. Le Leu; G.P. Young. 2017. Analysis of Anti Cancer Effect of Cincau Extract (Premna oblongifolia Merr) and Other Thypes of Non-Digestible Fibre Using Faecal Fermentation Supernantats and Coconuts. JCR Stangoulis Nutrient. mdpi.com

Pitojo, S. dan Zumiati. 2008. Cincau : Cara Pembuatan dan Variasi Olahannya. Penerbit PT. Agro Media Pustaka. Tanggerang. 
Rusmayasari. 2006. Pengaruh IBA, NAA, dan Air Kelapa Terhadap Pertumbuhan Stek Pucuk Meranti Bapa (Shorea selanica BL) (Skripsi). Institut Pertanian Bogor. Bogor.

Santoso, S.S. 2018. Peran Flavonoid Cincau Hijau (Premna obliongifolia) Terhadap Tumor Otak. Prosiding SEMNASTAN $2018: 53$ - 61

Setiawan, P. 2013. Pengaruh Perendaman Benih Kakao dalam Air Kelapa dan Pemberian Pupuk NPKMg (15-15-6-4) terhadap Pertumbuhan Bibit Kakao (Theobrema Kakao L.). J.online Agroekoteknologi 1 (4) : 37 - 40

Sundari, F. dan K.R. Ekawidyani. 2014. Minuman Cincau Hijau (Premna oblongifolia Merr) dapat Menurunkan Tekanan Darah pada Wanita Dewasa Penderita Hipertensi Ringan dan Sedang. J.Gizi dan Pangan 9 (3) : 203 - 210

Viza, R.Y. dan A. Ratih. 2018. Pengaruh Komposisi Media Tanam dan ZPT Air Kelapa terhadap Pertumbuhan Setek Pucuk Jeruk Kacang (Citrus reticulata Blanco). Jurnal Biologi Univ. Andalas 6 (2): 98-106

Widyastoety, D, Kusumo, S. dan Syafitri. 1997. Pengaruh Tingkat Ketuaan Air Kelapa dan Jenis Kelapa terhadap Pertumbuhan Plantet Anggrek Dendrobium. Jurnal. Hortikultura 7 (2): 768-772

Wulandari, R.C, R.Linda dan Mukarlina. 2013. Pertumbuhan Setek Melati putih (Jasminum sambac (L) W.Ait) dengan Pemberian Air Kelapa dan IBA. J. Protobiont 2 (2): 39-43 